\title{
RADIOCARBON DATING THE LATE UPPER PALEOLITHIC OF CANTABRIAN SPAIN: EL MIRÓN CAVE DATE LIST IV
}

\author{
Lawrence Guy Straus ${ }^{1,2} \bullet$ Manuel R González Morales ${ }^{2}$ - Thomas Higham ${ }^{3} \bullet$ Michael Richards $^{4} \bullet$ \\ Sahra Talamo ${ }^{4}$
}

\begin{abstract}
This fourth date list for the long cultural sequence in El Mirón Cave (Cantabria, Spain) reports on 19 new AMS assays for Solutrean, Initial, Lower, and Middle Magdalenian and Azilian levels, ranging from about 19 to 11 uncalibrated kyr. Key results are provision of further precision on the transition between the Solutrean and Magdalenian at the end of the Last Glacial Maximum and the very exact dating of a Magdalenian human burial and its relationship to both major living floors and closely associated rock art in the cave.
\end{abstract}

\section{INTRODUCTION}

One of the objectives of the El Mirón Cave Prehistoric Project since it inception in 1996 has been to date a long series of human occupations in a manner independent of supposedly temporally diagnostic artifacts. A deeply stratified site, this cave is an ideal place in which to study long-term change in human adaptations against the backdrop of major Last Glacial and Postglacial environmental changes (Straus and González Morales 2012a). The chronostratigraphic sequence includes levels ranging from the late Middle Paleolithic through the early Bronze Age and these now have been dated by 84 radiocarbon assays - one of the largest series of any single Stone Age site in Spain or even Europe. This brief note presents the fourth date list for the site.

El Mirón Cave is located at $260 \mathrm{~m}$ asl and is surrounded by $\geq 1000-\mathrm{m}$ summits in the Cantabrian Cordillera in eastern Cantabria Province, some $20 \mathrm{~km}$ from the Holocene shore of the Bay of Biscay, equidistant between the cities of Santander and Bilbao (Vizcaya). The huge mouth faces due west with a commanding view of the upper Asón River Valley and the vestibule is large, dry, and well sheltered. Readers are referred to the three earlier date lists published in Radiocarbon and the references therein for information on the site and its cultural sequence (Straus and González Morales 2003, 2007, 2010). These and other cited references can be consulted for an area map, site plan, and relevant stratigraphic sections. Radiocarbon is the ideal venue for the comprehensive, standardized publication of all the ${ }^{14} \mathrm{C}$ dates from this site.

Excavations in 2010, 2011, and 2013 were focused on the rear of the cave vestibule and on two aspects of the stratigraphic sequence: the Solutrean-Initial Magdalenian transition (Straus et al. 2014a,b) and an extraordinary human burial of Lower Magdalenian age (Straus et al. 2011). The timing and nature of the Solutrean-Magdalenian transition (pre- or post-17,000 uncal BP; abrupt or gradual) have been the subjects of debate in SW Europe for many decades, especially with the recent claims for a widespread Badegoulian technocomplex or tradition interposed between the Solutrean and the classic Magdalenian in Spain as well as in France, where it had originally been defined. The El Mirón burial is the first Magdalenian interment to be discovered on the Iberian Peninsula, although (in line with Magdalenian traditions in France and Germany, as summarized by Pettitt [2011]) there is other evidence in Spain of the postmortem manipulation of human remains, including the cranial "cups" found by Obermaier (1924) in the Lower Magdalenian horizon of nearby El Castillo Cave in 1911. This burial proved to be pene-contemporaneous with major Lower Magdalenian Level 17 and with the decoration of a large block that had fallen from the cave ceiling shortly before. Thus, considerable effort was placed in the final excavation campaigns on

1. Department of Anthropology, MSC01 1040, University of New Mexico, Albuquerque, NM 87131-0001, USA.

2. Instituto Internacional de Investigaciones Prehistóricas, Universidad de Cantabria, 39005 Santander, Spain.

3. Research Laboratory for Archaeology, Perrins Bldg., South Parks Road, Oxford University, Oxford OX1 3QY, UK.

4. Department of Human Evolution, Max Planck Institute for Evolutionary Anthropology, Deutscher Platz 6, 04103

Leipzig, Germany. 
dating the Solutrean, Initial, and Lower Magdalenian levels in the site, supplementing (and perhaps modifying) what was already known and providing a radiometric age for the burial and dates for the stratigraphically bracketing levels.

\section{THE NEW DATES}

We report herein 19 new dates. They include seven that were run by Thomas Higham and staff at the Oxford University Radiocarbon Accelerator Unit at the request of Adrian Lister and Meirav Meiri, who did an extensive DNA analysis on red deer from the whole El Mirón sequence to study the question of repopulation of northern Europe from an Iberian refugium after the Last Glacial Maximum (Meiri et al. 2013). Information on the Oxford laboratory's ultrafiltration pretreatment, target preparation, and AMS measurement methods is published in Bronk Ramsey et al. (2002) and Higham et al. (2006).

Table 1 El Miron Cave radiocarbon date list IV.

\begin{tabular}{llllllllll}
\hline Square & Level & Spit & Period & $\begin{array}{l}\text { Date }(\mathrm{BP}) \\
\pm 1 \sigma\end{array}$ & Material & Lab nr & $\pm 1 \sigma$ cal BP & $\begin{array}{l}\delta^{13} \mathrm{C} \\
(\%)\end{array}$ & C:N \\
\hline J3 & 11 & & AZ & $11,785 \pm 55$ & Bc & OxA-22087 & $13,720-13,550$ & -19.7 & 3.2 \\
J4 & 11.1 & & AZ/UM & $11,205 \pm 55$ & Bc & OxA-22088 & $13,130-13,020$ & -19.7 & 3.3 \\
J4 & 13 & & MM & $14,930 \pm 70$ & Bc & OxA-22089 & $18,270-18,040$ & -19.2 & 3.2 \\
H3 & 17 & & LM & $15,610 \pm 90$ & Bc & OxA-22093 & $18,950-18,760$ & -20.2 & 3.1 \\
W7 & 105 & 7 & MM? & $13,490 \pm 40$ & Bc & UG-9286 & $16,320-16,140$ & -19.0 & \\
W7 & 105 & 7 & MM? & $14,720 \pm 40$ & Tc & UG-18525 & $17,840-18,000$ & -18.5 & 3.4 \\
V7 & 104 & 4 & MM & $14,120 \pm 35$ & Tc & UG-15261 & $17,280-17,070$ & -18.8 & \\
U8 & 110 & 18 & LM & $14,760 \pm 70$ & Bc* & OxA-22091 & $18,070-17,860$ & -20.6 & 3.2 \\
U8 & 110 & 18 & LM & $14,795 \pm 75$ & Bc* & OxA-22092 & $18,110-17,890$ & -20.5 & 3.2 \\
W8 & 110 & & LM & $16,520 \pm 40$ & Bc & UG-10628 & $20,040-19,840$ & -21.0 & \\
T8 & 112 & 26 & LM & $15,430 \pm 75$ & Bc & OxA-22090 & $18,780-18,610$ & -20.1 & 3.5 \\
U10 & 117 & base & IM & $17,240 \pm 40$ & Bc & UG-15180 & $20,880-20,690$ & -19.9 & \\
U10 & 119 & 41 & IM & $17,230 \pm 40$ & Bc & UG-15182 & $20,870-20,680$ & -20.6 & \\
U10 & 119.2 & base & IM? & $17,620 \pm 40$ & Bc & UG-15181 & $21,430-21,190$ & -20.0 & \\
V10 & 127 & 15 & Sol & $19,230 \pm 50$ & Ch & UG-7216 & $23,300-23,020$ & -24.5 & \\
X7 & 503.1 & 5.1 & LM & $15,120 \pm 40$ & Ch & UG-7799 & $18,460-18,310$ & -23.3 & \\
X7 & 504 & 7 & LM & $15,740 \pm 40$ & Bc & UG-7217 & $19,040-18,900$ & -22.8 & \\
X7 & 504 & & LM & $15,460 \pm 40$ & hBc & MAMS-14585 & $18,790-18,670$ & -22.8 & 3.2 \\
X6 & 505 & 4 & LM & $15,670 \pm 40$ & Ch & UG-15183 & $18,960-18,840$ & -24.3 & \\
\hline
\end{tabular}

Notes: Bc: bone collagen; hBc: human bone collagen; Tc: tooth collagen; Ch: charcoal; *: same bone. All dates were determined by AMS and calibrated using the IntCal13 calibration curve and OxCal v 4.2 software (Reimer et al. 2013; Bronk Ramsey and Lee 2013). Squares H3, J3, J4 are in the outer vestibule Cabin area; T8, U8, U10, V7, W7, and W8 are in the vestibule rear Corral area; X6, X7 are in the Burial area behind the engraved block contiguous with the Corral.

Eleven assays were run by Alexander Cherkinsky at the University of Georgia Center for Applied Isotope Studies. The bone was cleaned by wire brush and washed, using an ultrasound bath. After cleaning, the dried bone was gently crushed to small fragments. The crushed bone was treated with $1 \mathrm{~N} \mathrm{HCl}$ at $4^{\circ} \mathrm{C}$ for $24 \mathrm{hr}$. The residue was filtered, rinsed with deionized water, and under slightly acid condition $(\mathrm{pH}=3)$ heated at $80^{\circ} \mathrm{C}$ for $6 \mathrm{hr}$ to dissolve collagen and leave humic substances in the precipitate. The collagen solution was then filtered to isolate pure collagen and dried out. The 
dried collagen was combusted at $575^{\circ} \mathrm{C}$ in an evacuated/sealed Pyrex ${ }^{\mathrm{TM}}$ ampoule in the presence of $\mathrm{Cu}$. The resulting carbon dioxide was cryogenically purified from the other reaction products and catalytically converted to graphite using the method of Vogel et al. (1984) (A Cherkinsky, personal communication, 27 August 2013).

Finally, bone collagen was extracted with ultrafiltration (as described by Talamo and Richards 2011) from a human fibula by Sahra Talamo in the Department of Human Evolution of the Max Planck Institute for Evolutionary Anthropology and then dated at the Klaus-Tschira AMS facility of the Curt Engelhorn Center in Mannheim at the request of Svante Pääbo. A C:N ratio is available for only one of the University of Georgia dates. All the assays were done by accelerator mass spectrometry (AMS). The results, including $\delta^{13} \mathrm{C}$ and $\mathrm{C}: \mathrm{N}$ values, are presented in Table 1.

The dates from Levels 11 and 11.1 in the Outer Vestibule confirm the dates run earlier by Cherkinsky from Level 11.1 and from Level 102.1 at the Vestibule Rear. They also square with what is known generally now throughout the Cantabrian region about the gradual, mosaic-like transition between the Final Magdalenian and the Azilian (an Epi-Magdalenian industry) at between around 12-11.5 uncal kyr (Fernández Tresguerres 2007). The presence of simplified stone tool assemblages, including backed micropoints and thumbnail endscrapers (plus an ochre-stained cobble in Level 11.1), fit perfectly with the dates, although the lack of either round- or flat-section antler harpoons really makes specific normative cultural attributions for Levels 11.1 and 11.2 (or 102.1) problematic (González Morales and Straus 2012). The dates from Levels 13, 105, and 104 correspond to the Middle Magdalenian of Cantabrian Spain and the adjacent French Pyrenees (González Sainz and Utrilla 2005). However, none of these levels at El Mirón is well endowed with artifacts and classic diagnostics of the Middle Magdalenian (proto-harpoons, perforated effigies of horse or caprine heads cut out of hyoid bones, decorated and perforated disks cut out of flat bones) are lacking and there are no lithic fossil directors for this phase. The dates at least confirm that the cave continued to be utilized by humans on a more sporadic, limited basis than had been the case with the intensive, frequent, multipurpose residential occupations of the Lower and Initial Magdalenian. Levels 106104 are discontinuous, rather indistinct (and thus difficult to follow laterally), and possibly disturbed (by rodents and/or running water?), thus perhaps explaining the apparent stratigraphic incoherence of the dates. This new pattern of human use of El Mirón, established in the Middle Magdalenian, continued in the Upper Magdalenian and Azilian and became even more ephemeral during the Mesolithic time range (9-6 uncal kyr), when the cave was only occasionally visited, presumably by people who were living around the Río Asón estuary, where there are several shell midden sites. A peculiar fact about Levels 104-105 is that they yielded several loose human teeth, two of which are among the specimens reported here: a deciduous premolar from 104 and a canine from 105. These are clearly unrelated to the partial human skeleton that was found in an adjacent area of the cave vestibule rear, but stratigraphically lower and dated to about a millennium earlier (see below).

Lower Magdalenian-age dates are the most abundant ones from the entire site, with rich occupation layers in the Outer Vestibule (especially Level 17) and Vestibule Rear (Levels 116-109), as well as traces of human activity in the Inner Cave and on the ramp connecting the Vestibule and Inner Cave. Now there is a fourth area pertaining to this period of major use of the cave during the late Oldest Dryas (late Greenland Stadial 2): a human burial whose bones are stained with red ochre and placed in sediments stained with red ochre (Level 504) in a hollow between an angle of the cave wall and a $\sim 2$-m-long roof-fall block. The burial layer is also overlain and underlain by Lower Magdalenian levels (503.1 and 505, respectively). The new Level 17 date confirms an age averaging about 15.5 uncal kyr, with a total of five similar dates from this flat, massive, but rapidly formed horizon replete with fire-cracked rock-filled hearths, masses of ibex and red deer remains, lithic 
knapping debris and stone tools, antler points, bone needles, perforated ungulate teeth, and red deer scapulae striation-engraved with images of animals - an absolute diagnostic of this Magdalenian phase in Cantabria (González Morales and Straus 2009; Nakazawa et al. 2009). In contrast, Level 110 in the Vestibule rear poses a dating dilemma. There are two statistically identical OxA dates of 14.8 uncal kyr on the same bone from square U8 and two very similar dates of 16.1 and 16.5 uncal kyr (the first a conventional assay; the second by AMS - both run by Cherkinsky at Geochron Labs and Georgia, respectively) from squares V8 and W8 (i.e. 1-2 $\mathrm{m}$ to the east and upslope from the U8 dates). The latter pair of dates are on samples collected adjacent to and directly under the engraved block, respectively. The possibility exists that a combination of the fall of the block and the structural slope that exists in the vestibule rear translated to a miscorrelation during excavation between what was originally defined as Level 110 against the face of the block (which may have significantly depressed the sediments upon which it had landed) and the layer further west, from which the U8 bone had been recovered. At any rate, the block seems to have fallen soon after about 16.5 uncal BP per the UG-10628 date. Another OxA date on bone from Level 112 in square T8 would seem to confirm the pattern of some younger dates west of the block (as also seen in two previously reported Level 111 dates from squares V8 vs. U7-older to the east, younger to the west).

Immediately east of the block the sequence of levels above, in and below the human burial is dated quite coherently and entirely relates to the Lower Magdalenian (as confirmed by the characteristic antler point types, core-scrapers, abundant backed bladelets and microlithic triangles) (Straus et al. 2011). Overlying Level 503.1 was dated on charcoal from a hearth atop the burial to 15.1 uncal kyr; a human fibula in Level 504 was dated to 15.5 uncal kyr; the ochre-stained backfill (Level 504) of the artificial pit and/or enlarged natural basin in which the corpse (now represented by $\sim 100$ ochrestained human bones, not including the skull) had been buried yielded a date of 15.7 uncal kyr on an animal bone; and immediately underlying Level 505 also provided a date of 15.7 uncal kyr. Probably the burial pit/basin was partially dug into Level 505 and then was filled with material derived from it and Level 504, together with hematite ochre powder and chunks. The adjacent eastern face of the block next to the burial was also stained with red ochre and probably the western face was engraved at about this time (García Díez et al. 2012). All of this seems to have happened relatively quickly after the block fell. El Mirón was the scene of a gamut of human activities during the classic Cantabrian Lower Magdalenian between about 16-14.5 uncal kyr, including tool manufacture, carcass butchery, marrow and grease extraction, cooking, (presumed) clothes and moccasin fabrication and sewing, ornament-making, art, rituals, and burial. This wealth and diversity of activities mirrors what was going on during the same period at major hub or base campsites on or at the edge of the coastal plain, such as Altamira and El Juyo in Cantabria or Santimamiñe in Vizcaya (Straus and González Morales 2012b).

The nature and timing of the transition between the Solutrean and Magdalenian technocomplexes has been the subject of debate for many years and has notably focused on the stratigraphic sequences in La Riera and Las Caldas Cave (Asturias) since the late 1970s (Corchón 2005). At issue is whether the classic Solutrean hunting technology (leaf-shaped and shouldered stone points, often made with invasive retouch) was abruptly replaced by a totally new (and perhaps nonlocal, i.e. French) "culture" (sometimes called the Badegoulian or Magdalenian 0), or whether there was more gradual, in situ change, but with basic continuity of peoples, adaptations , and technologies, including both large, archaic-looking sidescrapers, denticulates and notches, and backed bladelets and other Upper Paleolithic-type implements and certain classes of osseous artifacts such as centrally flattened antler points and bone needles. The latter scenario is envisioned as a process of "desolutreanization" in which the classic stone points were still present, but were becoming rarer. El Mirón Levels 127-122 
are clearly attributable in the normative sense to the Solutrean, given the relatively large numbers of various kinds of laurel and willow leaf, concave base, and shouldered points (almost all fragments) found therein. Among the new dates is one from the lowest of these levels (127): 19.2 uncal kyr. Previously, the overlying Solutrean levels had been coherently dated between 19.0-18.4 uncal kyr. New dates were run on overlying levels 119.2 (base), 119, and 117 (base) to try to resolve seeming inconsistencies among the earlier series of dates from the levels immediately above the Solutrean sequence. The new date for the base of Level 119.2 (in contact with the uppermost Solutrean layer) is $17.6 \mathrm{kyr}(20.7 \mathrm{cal} \mathrm{BP})$, whereas the original date from a bit higher up in 119.2 is 16.3 uncal kyr. On the other hand, the new date for Level 119 (17.3 uncal kyr) is close to the original date (17.0 uncal kyr), and the new date for the base of Level 117 (17.2 uncal kyr) is congruent with the original date for the middle of the level (17.1 uncal kyr). While the very small lithic assemblage from Level 121 and the assemblages from 119.3-119.1 (a series of pit fills) lack Solutrean points, there are two in Initial Magdalenian Level 119. Similarly, in a deep 1- $\mathrm{m}^{2}$ test pit in the center of the Mid-Vestibule Trench, the lowest level reached (313) was previously dated to 17.4 uncal kyr, but lacks Solutrean points, possibly as a consequence of the small area sampled. In terms of macroliths, microliths, and osseous artifacts, there are many similarities between assemblages normatively labeled as Solutrean and Initial Magdalenian (Straus et al. 2014a,b), but without evidence of an abrupt replacement of one culture or people by another, despite the undoubted existence of social contacts between Cantabrian Spain and Pyrenean France in this period, which would intensify (or at least become even more manifest) in the Middle Magdalenian. It is possible that there was a depositional hiatus between Levels 121 and 119.3 with several "missing" centuries.

In sum, El Mirón Cave, in addition to containing an invaluable sequence of well-dated residential levels pertaining to the early and late Cantabrian Neolithic, Chalcolithic, and early Bronze Age, now has a full and extraordinarily thoroughly (and generally coherently) dated series of Initial, Lower, Middle, and Upper Magdalenian layers (including a rare human burial), bracketed below by a series of Solutrean levels (and discrete dated evidence of earlier Gravettian and Mousterian visits to the cave) and above by Azilian and Mesolithic ones. This record is rivaled by the classic (but early excavated) regional sites of El Castillo and Isturitz, but few others.

\section{ACKNOWLEDGMENTS}

Research at El Mirón Cave has been authorized and partially financed by the Consejería de Cultura, Gobierno de Cantabria. Funding for the most recent excavation campaigns has also come from the L.S.B. Leakey Foundation, the National Geographic Society, the University of New Mexico, and the Fund for Stone Age Research (Jean and Ray Auel, principal donors). We wish to thank Svante Pääbo and his associates at the Max Planck Institute for Evolutionary Anthropology, Adrian Lister and Meirav Meiri at the Natural History Museum, and Alexander Cherkinsky at the University of Georgia for the dates reported here, as well the Universidad de Cantabria and the Town and citizens of Ramales de la Victoria for their support of the project. Last but not least, we are indebted to all the students and collaborating scientists who have worked diligently on the project since 1996. Our thanks as well to two anonymous reviewers and the Editor of Radiocarbon for their recommendations on the initial draft of this article. An important future project will be the Bayesian analysis of all 84 radiocarbon dates from El Mirón.

\section{REFERENCES}

Bronk Ramsey C, Higham T, Owen D, Pike A, Hedges R. 2002. Radiocarbon dates from the Oxford AMS System: Datelist 31. Archaeometry 44(3):1-149. Bronk Ramsey C, Lee S. 2013. Recent and planned developments of the program OxCal. Radiocarbon 55(2-3):720-30.

Corchón MS. 2005. El Magdaleniense en la Cornisa Cantábrica: nuevas investigaciones y debates ac- 
tuales. In: Bicho N, editor. O Paleolítico. Faro: Promontoria Monográfica 2. p 15-38.

Fernández Tresguerres J. 2007. El final del Paleolítico en los espacios cantábricos: el Aziliense. In: Fano MA, editor. Las Sociedades del Paleolítico en la Región Cantábrica. Kobie. Anejo 8. p 309-36.

García Díez M, González Morales M, Straus LG. 2012. El grafismo rupestre paleolítico de la cueva de El Mirón (Ramales de la Victoria, Cantabria, España): una propuesta para su datación estratigráfica. Trabajos de Prehistoria 69:21-36.

González Morales M, Straus LG. 2009. Extraordinary early Magdalenian finds from El Mirón Cave, Cantabria (Spain). Antiquity 83(320):267-81.

González Morales M, Straus LG. 2012. Terminal Magdalenian/Azilian at El Mirón Cave (Ramales de la Victoria, Cantabria) and the Río Asón Valley. In: Muñiz J, editor. Ad Orientem. Oviedo: Ménsula. p 189-215.

González Sainz C, Utrilla P. 2005. Problemas actuales en la organización y datación del Magdaleniense en la región cantábrica. In: Bicho N, editor. O Paleolítico. Faro: Promontoria Monográfica 2. p 39-47.

Higham T, Jacobi R, Bronk Ramsey C. 2006. AMS radiocarbon dating of ancient bone using ultrafiltration. Radiocarbon 48(2):179-95.

Meiri M, Lister A, Higham T, Stewart J, Straus LG, Obermaier H, González Morales M, Marín-Arroyo AB, Barnes I. 2013. Late-glacial recolonization and phylogeography of European red deer (Cervus elaphus L.). Molecular Ecology 22(18):4711-22.

Nakazawa Y, Straus LG, González Morales M, Cuenca D, Caro J. 2009. On stone-boiling technology in the Upper Paleolithic: behavioral implications from an Early Magdalenian hearth in El Mirón Cave, Cantabria, Spain. Journal of Archaeological Science 36(3):684-93.

Obermaier H. 1924. Fossil Man in Spain. New Haven: Yale University Press.

Pettitt P. 2011. The Palaeolithic Origins of Human Burial. London: Routledge.

Reimer PJ, Bard E, Bayliss A, Beck JW, Blackwell PG, Bronk Ramsey C, Buck CE, Cheng H, Edwards RL, Friedrich M, Grootes PM, Guilderson TP, Haflidason H, Hajdas I, Hatté C, Heaton TJ, Hoffman DL, Hogg AG, Hughen KA, Kaiser KF, Kromer B, Manning SW, Niu M, Reimer RW, Richards DA, Scott
EM, Southon JR, Staff RA, Turney CSM, van der Plicht J. 2013. IntCal13 and Marine13 radiocarbon age calibration curves $0-50,000$ years cal BP. Radiocarbon 55(4):1869-87.

Straus LG, González Morales M. 2003. El Mirón Cave and the ${ }^{14} \mathrm{C}$ chronology of Cantabrian Spain. Radiocarbon 45(1):41-58.

Straus LG, González Morales M. 2007. Further radiocarbon dates for the Upper Paleolithic of El Mirón Cave. Radiocarbon 49(3):1205-14.

Straus LG, González Morales M. 2010. The radiocarbon chronology of El Mirón Cave (Cantabria, Spain): new dates for the Initial Magdalenian occupations. Radiocarbon 52(1):33-9.

Straus LG, González Morales M. 2012a. El Mirón Cave, Cantabrian Spain. Albuquerque: University of New Mexico Press.

Straus LG, González Morales M. 2012b. The Magdalenian settlement of the Cantabrian region (northern Spain): the view from El Mirón Cave. In: Straus LG, Terberger T, Leesch D, editors. The Magdalenian Settlement of Europe. Quaternary International 272-273:111-24.

Straus LG, González Morales M, Carretero JM. 2011. Lower Magdalenian secondary human burial in El Mirón Cave, Cantabria, Spain. Antiquity 85(330):1151-64.

Straus LG, González Morales M, Marín Arroyo AB, Iriarte MJ. 2014a. The human occupations of $\mathrm{El}$ Mirón Cave (Ramales de la Victoria, Cantabria, Spain) during the Last Glacial Maximum/Solutrean period. In: Avezuela B, Jordá J, editors. De Punta a Punta. El Solutrense en los Albores del Siglo XXI. Espacio, Tiempo y Forma, Serie I, Prehistoria y Arqueología. Nueva Época 5. p 419-32.

Straus LG, González Morales M, Fontes L. 2014b. Initial Magdalenian artifact assemblages in El Mirón Cave (Ramales de la Victoria, Cantabria, España): a preliminary report. Zephyrus 73:45-65.

Talamo S, Richards M. 2011. A comparison of bone pretreatment methods for AMS dating of samples $>30,000$ BP. Radiocarbon 53(3):443-9.

Vogel JS, Southon JR, Nelson DE, Brown TA. 1984. Performance of catalytically condensed carbon for use in accelerator mass spectrometry. Nuclear Instruments and Methods in Physics Research B 5(2):289-93. 